\title{
Decarboxylative trifluoromethylthiolation of pyridylacetates
}

\author{
Ryouta Kawanishi, Kosuke Nakada and Kazutaka Shibatomi ${ }^{*}$
}

\author{
Full Research Paper \\ Address: \\ Department of Applied Chemistry and Life Science, Toyohashi \\ University of Technology, 1-1 Hibarigaoka, Tempaku-cho, Toyohashi \\ 441-8580, Japan \\ Email: \\ Kazutaka Shibatomi* - shiba@chem.tut.ac.jp \\ ${ }^{*}$ Corresponding author \\ Keywords: \\ decarboxylation; fluorinated compounds; pyridine compounds; \\ trifluoromethylthiolation
}

Open Access

Beilstein J. Org. Chem. 2021, 17, 229-233.
https://doi.org/10.3762/bjoc.17.23
Received: 31 October 2020
Accepted: 04 January 2021
Published: 25 January 2021
This article is part of the thematic issue "Organo-fluorine chemistry V".
Guest Editor: D. O'Hagan
@ 2021 Kawanishi et al.; licensee Beilstein-Institut.
License and terms: see end of document.

\begin{abstract}
Decarboxylative trifluoromethylthiolation of lithium pyridylacetates was achieved using $N$-(trifluoromethylthio)benzenesulfonimide as the electrophilic trifluoromethylthiolation reagent. The reaction afforded the corresponding trifluoromethyl thioethers in good yield. Furthermore, the preparation of lithium pyridylacetates by saponification of the corresponding methyl esters and subsequent decarboxylative trifluoromethylthiolation were performed in a one-pot fashion.
\end{abstract}

\section{Introduction}

The pyridine ring is found in numerous biologically active compounds. Therefore, efficient methods for synthesizing substituted pyridines are in high demand in pharmaceutical and agricultural chemistry [1,2]. Because of the unique features of fluorine atoms, fluorinated functional groups have also been recognized as important substructures in the design of medicinally relevant compounds [3-6]. Introducing a trifluoromethylthio group $\left(\mathrm{CF}_{3} \mathrm{~S}-\right)$, which has high lipophilicity and strong electron-withdrawing properties, into medicinal compounds can improve their pharmacokinetic properties [7-11]. Hence, the development of a synthetic method for the preparation of trifluoromethyl thioethers has recently attracted much attention [12-15].

Previously, our research group achieved decarboxylative functionalization of tertiary $\beta$-ketocarboxylic acids by exploiting their special ability to readily undergo decarboxylation [16-21].
During the course of this study, we found that lithium pyridylacetates undergo decarboxylative fluorination upon treatment with an electrophilic fluorination reagent to afford fluoromethylpyridines under catalyst-free conditions. Furthermore, we demonstrated the one-pot synthesis of fluoromethylpyridines from methyl pyridylacetates by saponification of methyl esters and subsequent decarboxylative fluorination (Scheme 1a) [21]. Herein, we describe the application of this method to decarboxylative trifluoromethylthiolation with an electrophilic trifluoromethylthiolation reagent (Scheme 1b) [22], which enables easy installation of the trifluoromethylthio group at a pyridylic carbon.

\section{Results and Discussion}

First, we synthesized lithium 2-pyridylacetate 1a according to our previously reported procedure [21] and subjected it to decarboxylative trifluoromethylthiolation with $\mathrm{N}$-trifluoro- 
a) our previous study

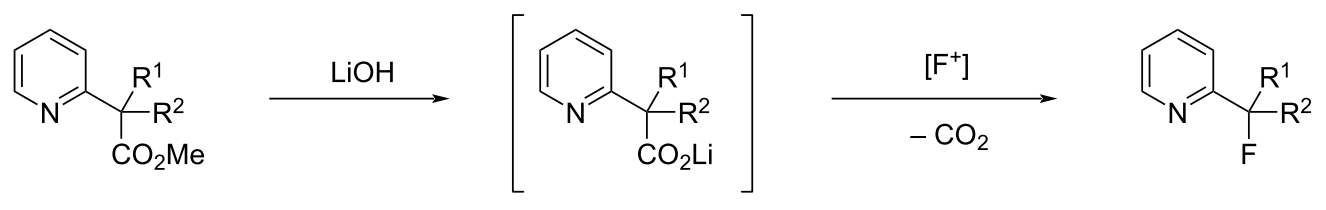

b) this work

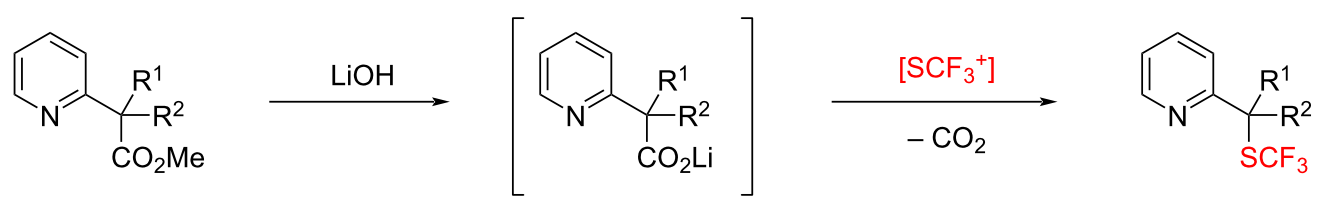

Scheme 1: Electrophilic decarboxylative functionalization of 2-pyridylacetates.

methylthiosuccinimide (4) in DMF at room temperature for 15 h. However, the desired product $\mathbf{2 a}$ was not observed (Table 1, entry 1). The use of $N$-trifluoromethylthiophthalimide (5) did not afford 2a either (Table 1, entry 2). Fortunately, the use of $N$-(trifluoromethylthio)dibenzenesulfonimide 6 [23] gave 2a in
$14 \%$ yield, along with the protonated product $\mathbf{3 a}$ in $31 \%$ yield (Table 1, entry 3 ). The yield of $\mathbf{2 a}$ could be improved to $30 \%$ by adding MS $4 \AA$ to the reaction mixture (Table 1, entry 4). Screening of various solvents revealed that THF was the best choice for this reaction (Table 1, entries 4-11), and the yield of

Table 1: Screening of reaction conditions.<smiles>CC(Cc1ccccc1)(C(=O)OCl)c1ccccn1</smiles>

$1 a$

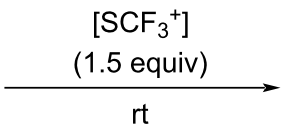<smiles>CC(Cc1ccccc1)(c1ccccn1)C(F)(F)F</smiles>

$2 a$<smiles>CC(Cc1ccccc1)c1ccccn1</smiles>

$3 a$

\section{$\left[\mathrm{SCF}_{3}{ }^{+}\right]$}<smiles>O=C1CCC(=O)N1C(F)(F)F</smiles>

4<smiles>O=C1c2ccccc2C(=O)N1C(F)(F)F</smiles>

5

$$
\begin{aligned}
& 0,000 \\
& \mathrm{Ph}^{-} \mathrm{S}^{-} \mathrm{N}_{1}-\mathrm{S}^{-} \mathrm{Ph}
\end{aligned}
$$

\begin{tabular}{|c|c|c|c|c|c|}
\hline entry & {$\left[\mathrm{SCF}_{3}{ }^{+}\right]$} & solvent & time (h) & yield of $\mathbf{2 a}(\%)$ & yield of $\mathbf{3 a}(\%)$ \\
\hline 1 & 4 & DMF & 15 & 0 & 0 \\
\hline 2 & 5 & DMF & 72 & 0 & 0 \\
\hline 3 & 6 & DMF & 3 & 14 & 31 \\
\hline $4^{a}$ & 6 & DMF & 5 & 30 & 34 \\
\hline $5^{\mathrm{a}}$ & 6 & DMSO & 5 & 64 & 21 \\
\hline $6^{a}$ & 6 & acetonitrile & 8 & 77 & 0 \\
\hline $7^{a}$ & 6 & toluene & 168 & 72 & 0 \\
\hline $8^{a}$ & 6 & $\mathrm{CH}_{2} \mathrm{Cl}_{2}$ & 72 & 54 & 0 \\
\hline $9^{a}$ & 6 & $t$-BuOMe & 72 & 55 & 0 \\
\hline $10^{\mathrm{a}}$ & 6 & 1,4-dioxane & 9 & 75 & 0 \\
\hline $11^{a}$ & 6 & THF & 8 & 89 & 0 \\
\hline 12 & 6 & THF & 8 & 63 & 26 \\
\hline $13^{a, b}$ & 6 & THF & 8 & 70 & 0 \\
\hline
\end{tabular}

6

aThe reaction was carried out with MS $4 \AA$ ( $180 \mathrm{mg} / 0.2 \mathrm{mmol}) ;{ }^{b} 1.1$ equiv of 6 was used. 
2a was dramatically improved to $89 \%$ (Table 1, entry 11). In the absence of MS $4 \AA$, the yield of $2 \mathbf{a}$ was diminished even when the reaction was carried out in THF (Table 1, entry 12).

With the optimized reaction conditions in hand, we examined the one-pot synthesis of 2a from methyl ester 7a. Methyl 2-pyridylacetate 7a were saponified with lithium hydroxide in a $\mathrm{MeOH} / \mathrm{H}_{2} \mathrm{O}$ system. After completion of the reaction, the solvents were evaporated under reduced pressure. Then, THF, MS $4 \AA$, and 6 were added to the residue, and the mixture was stirred at room temperature for $8 \mathrm{~h}$. This reaction successfully afforded the desired product 2a in $85 \%$ yield over two steps (Scheme 2).

Encouraged by the aforementioned result, we applied this method to several 2-pyridylacetates (Scheme 3). Methyl 2-pyridylacetates $\mathbf{7 b}-\mathbf{d}$ with arylmethyl substituents furnished the corresponding trifluoromethylthiolated products $\mathbf{2 b - d}$ in good yields. $\alpha, \alpha$-Dialkyl-2-pyridylacetates $7 \mathbf{e}-\mathbf{g}$ also gave the

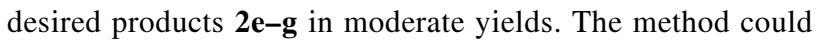
also be applied to substrates with quinoline and isoquinoline backbones to afford the corresponding products $2 \mathbf{h}$ and $\mathbf{2 i}$. In addition, the reaction of $\alpha$-monosubstituted 2-pyridylacetate $\mathbf{8}$ was performed to yield the corresponding mono-trifluoromethylthiolated product 9 in 36\% yield, along with $6 \%$ yield of disubstituted product 10 (Scheme 4). Increasing the amount of $\mathbf{6}$ did not improve the yield of products $\mathbf{9}$ and $\mathbf{1 0}$ significantly.

Based on the abovementioned results and our previous study on decarboxylative fluorination [21], we propose a plausible mechanism for this reaction, as outlined in Scheme 5. An electrophilic sulfur atom of $\mathbf{6}$ approaches the nitrogen atom on the pyridine ring to promote decarboxylation via the formation of $N$-trifluoromethylthio-2-alkylidene-1,2-dihydropyridine intermedi-

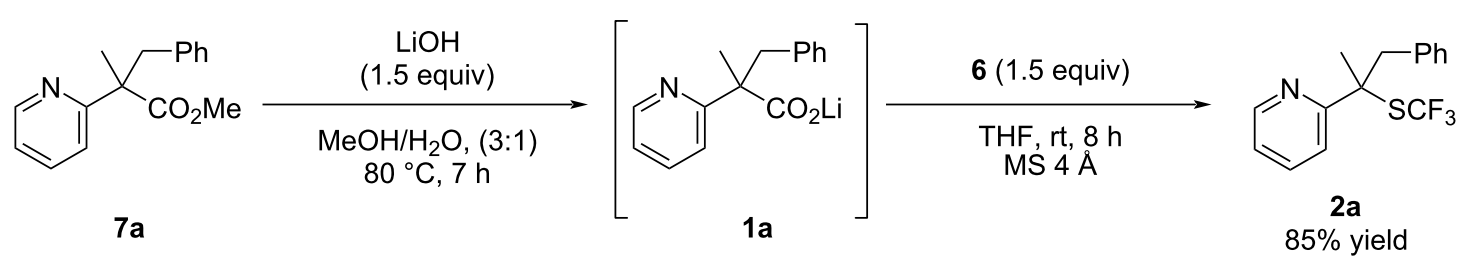

Scheme 2: One-pot procedure for the synthesis of $2 a$

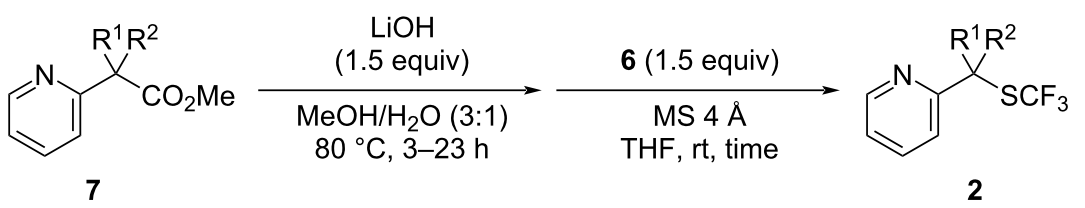<smiles>CC(Cc1ccccc1)(c1ccccn1)C(F)(F)F</smiles>

$2 \mathrm{a}$

$8 \mathrm{~h}, 85 \%$<smiles>CC(Cc1cccs1)(c1ccccn1)C(F)(F)F</smiles>

$2 \mathbf{b}$<smiles>CC(Cc1ccco1)(c1ccccn1)C(F)(F)F</smiles>

2c

$10 \mathrm{~h}, 87 \%$<smiles>CC(Cc1ccc2ccccc2c1)(c1ccccn1)C(F)(F)F</smiles>

2d<smiles>CC(F)(F)CCCCC(C)(c1ccccn1)C(F)(F)F</smiles>

$2 e$<smiles>CC(C)C(C)(c1ccccc1)c1ccccn1</smiles>

$2 f$

$11 \mathrm{~h}, 53 \% \mathrm{a}, \mathrm{b}$<smiles>CC(c1ccccn1)(C1CCCC1)C1CCCC1</smiles>

$2 \mathrm{~g}$

10 h, $46 \%^{a}$<smiles>CC(C)(c1ccc2ccccc2n1)[Si](F)(F)F</smiles>

$2 \mathrm{~h}$

$5 \mathrm{~h}, 71 \%^{\mathrm{a}}$<smiles>CC(C)(c1nccc2ccccc12)[Si](F)(F)F</smiles>

2i

$7 \mathrm{~h}, 77 \%^{\mathrm{c}}$

Scheme 3: Substrate scope. a Saponification was carried out with 2.5 equiv of LiOH, and 2.5 equiv of 6 was used for trifluoromethylthiolation. b Saponification of 7 was carried out for $39 \mathrm{~h}$. 'Saponification was carried out with 2.5 equiv of LiOH under reflux conditions, and 2.5 equiv of 6 was used for trifluoromethylthiolation. 

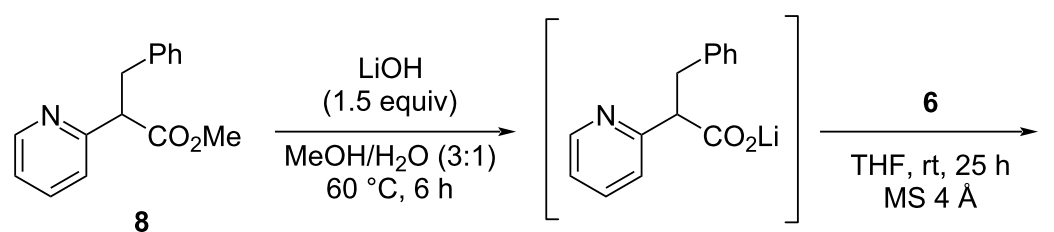<smiles>FC(c1ccccc1)C(Cc1ccccc1)c1ccccn1</smiles>

9<smiles>FC(F)(F)C(Cc1ccccc1)(c1ccccn1)C(F)(F)F</smiles>

10

\begin{tabular}{ccc}
\hline $\mathbf{6}$ & yield of $\mathbf{9}$ & yield of $\mathbf{1 0}$ \\
\hline 1.1 equiv & $36 \%$ & $6 \%$ \\
5.0 equiv & $34 \%$ & $11 \%$
\end{tabular}

Scheme 4: Reaction of $\alpha$-monosubstituted 2-pyridylacetates.<smiles>[R]C([R])(C(=O)O)c1ccccn1</smiles><smiles></smiles>

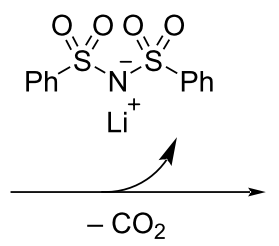<smiles>[R]C1=CC=CN2[Se]C=CC=C12</smiles><smiles>C1CCCC1</smiles><smiles>[R]C([R])([AsH2])c1ccccn1</smiles>

Scheme 5: Proposed reaction pathway.

ate $\mathbf{I}$, which immediately isomerizes to afford $\mathbf{2}$ (Scheme 5). Methyl 4-pyridylacetate $\mathbf{1 1}$ also gave the corresponding trifluoromethylthiolated product $\mathbf{1 2}$ in $29 \%$ yield (Scheme 6), where the reaction was assumed to proceed via the $N$-trifluoromethylthio-4-alkylidene-1,4-dihydropyridine intermediate. In contrast, methyl 3-pyridylacetate $\mathbf{1 3}$ did not yield the trifluoromethylthiolated product at all, despite complete saponification of the methyl ester.

\section{Conclusion}

In conclusion, we demonstrated the decarboxylative trifluoromethylthiolation of lithium 2- and 4-pyridylacetates to synthesize pyridine derivatives with a trifluoromethylthio group at a tertiary carbon center adjacent to the pyridine ring. Furthermore, saponification of methyl pyridylacetates and subsequent decarboxylative trifluoromethylthiolation of the resulting lithium salts were performed in a one-pot fashion. This method can<smiles>COC(=O)C(C)(Cc1ccc2ccccc2c1)c1ccncc1</smiles>

11<smiles>COC(=O)C(C)(Cc1ccc2ccccc2c1)c1cccnc1</smiles>

13

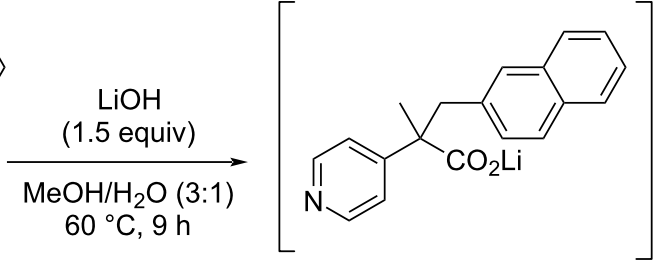

\section{6 ( 1.5 equiv) \\ THF, rt, $3 \mathrm{~h}$ MS $4 \AA$}<smiles>CC(Cc1ccc2ccccc2c1)(C(=O)O)c1cccnc1</smiles><smiles>CC([As])(Cc1ccc2ccccc2c1)c1ccncc1</smiles>

$29 \%$ yield<smiles>CC([AsH2])(Cc1ccc2ccccc2c1)c1cccnc1</smiles> 
easily convert an ester group into a trifluoromethylthio group. The resulting trifluoromethyl thioethers would be useful for the preparation of various medicinally relevant compounds.

\section{Supporting Information}

\section{Supporting Information File 1}

Experimental procedures, characterization data, and copies of NMR spectra.

[https://www.beilstein-journals.org/bjoc/content/ supplementary/1860-5397-17-23-S1.pdf]

\section{Funding}

This study was supported by the Grants-in-Aid for Scientific Research (B) (18H01974) from JSPS and the Toyota RIKEN Scholar Program from the Toyota Physical and Chemical Research Institute.

\section{ORCID ${ }^{\circledR}$ iDs}

Kazutaka Shibatomi - https://orcid.org/0000-0001-6368-4823

\section{References}

1. Taylor, R. D.; MacCoss, M.; Lawson, A. D. G. J. Med. Chem. 2014, 57, 5845-5859. doi:10.1021/jm4017625

2. Vitaku, E.; Smith, D. T.; Njardarson, J. T. J. Med. Chem. 2014, 57, 10257-10274. doi:10.1021/jm501100b

3. Müller, K.; Faeh, C.; Diederich, F. Science 2007, 317, 1881-1886. doi:10.1126/science.1131943

4. Purser, S.; Moore, P. R.; Swallow, S.; Gouverneur, V. Chem. Soc. Rev. 2008, 37, 320-330. doi:10.1039/b610213c

5. Wang, J.; Sánchez-Roselló, M.; Aceña, J. L.; del Pozo, C.; Sorochinsky, A. E.; Fustero, S.; Soloshonok, V. A.; Liu, H. Chem. Rev. 2014, 114, 2432-2506. doi:10.1021/cr4002879

6. Zhu, Y.; Han, J.; Wang, J.; Shibata, N.; Sodeoka, M.; Soloshonok, V. A.; Coelho, J. A. S.; Toste, F. D. Chem. Rev. 2018, 118, 3887-3964. doi:10.1021/acs.chemrev.7b00778

7. Leo, A.; Hansch, C.; Elkins, D. Chem. Rev. 1971, 71, 525-616. doi:10.1021/cr60274a001

8. Hansch, C.; Leo, A.; Taft, R. W. Chem. Rev. 1991, 91, 165-195. doi:10.1021/cr00002a004

9. Landelle, G.; Panossian, A.; Leroux, F. R. Curr. Top. Med. Chem. 2014, 14, 941-951. doi:10.2174/1568026614666140202210016

10. Leroux, F.; Jeschke, P.; Schlosser, M. Chem. Rev. 2005, 105, 827-856. doi:10.1021/cr040075b

11. Manteau, B.; Pazenok, S.; Vors, J.-P.; Leroux, F. R. J. Fluorine Chem. 2010, 131, 140-158. doi:10.1016/j.jfluchem.2009.09.009

12. Toulgoat, F.; Alazet, S.; Billard, T. Eur. J. Org. Chem. 2014, 2415-2428. doi:10.1002/ejoc.201301857

13. Xu, X.-H.; Matsuzaki, K.; Shibata, N. Chem. Rev. 2015, 115, 731-764. doi:10.1021/cr500193b

14. Barata-Vallejo, S.; Bonesi, S.; Postigo, A. Org. Biomol. Chem. 2016, 14, 7150-7182. doi:10.1039/c6ob00763e
15. Barthelemy, A.-L.; Magnier, E.; Dagousset, G. Synthesis 2018, 50, 4765-4776. doi:10.1055/s-0037-1611278

16. Shibatomi, K.; Kitahara, K.; Sasaki, N.; Kawasaki, Y.; Fujisawa, I.; Iwasa, S. Nat. Commun. 2017, 8, 15600. doi:10.1038/ncomms 15600

17. Katada, M.; Kitahara, K.; Iwasa, S.; Shibatomi, K. Synlett 2018, 29 , 2408-2411. doi:10.1055/s-0037-1611019

18. Naruse, A.; Kitahara, K.; Iwasa, S.; Shibatomi, K. Asian J. Org. Chem. 2019, 8, 691-693. doi:10.1002/ajoc.201900072

19. Kawanishi, R.; Hattori, S.; Iwasa, S.; Shibatomi, K. Molecules 2019, 24 2773. doi:10.3390/molecules24152773

20. Kitahara, K.; Mizutani, H.; Iwasa, S.; Shibatomi, K. Synthesis 2019, 51, 4385-4392. doi:10.1055/s-0039-1690009

21. Kawanishi, R.; Phongphane, L.; Iwasa, S.; Shibatomi, K. Chem. - Eur. J. 2019, 25, 7453-7456. doi:10.1002/chem.201900565

22. Shao, X.; Xu, C.; Lu, L.; Shen, Q. Acc. Chem. Res. 2015, 48, 1227-1236. doi:10.1021/acs.accounts.5b00047

23. Liu, X.; An, R.; Zhang, X.; Luo, J.; Zhao, X. Angew. Chem., Int. Ed. 2016, 55, 5846-5850. doi:10.1002/anie.201601713

\section{License and Terms}

This is an Open Access article under the terms of the Creative Commons Attribution License (https://creativecommons.org/licenses/by/4.0). Please note that the reuse, redistribution and reproduction in particular requires that the author(s) and source are credited and that individual graphics may be subject to special legal provisions.

The license is subject to the Beilstein Journal of Organic Chemistry terms and conditions: (https://www.beilstein-journals.org/bjoc/terms)

The definitive version of this article is the electronic one which can be found at: https://doi.org/10.3762/bjoc.17.23 